\title{
Universality of Anti-A and Anti-B Human Isolysins ${ }^{1}$
}

\author{
L. Daufi and P. Rondell \\ Department of Physiology, University of Michigan Medical Srhool, Ann Arbor, Mich.
}

Many studies of $\mathrm{ABO}$ isolysins have indicated that some $\mathrm{A}, \mathrm{B}$, and $O$ sera show no isohemolytic activity. The apparent incidence of $\mathrm{ABO}$ isolysins in human sera varies widely, from $0.24 \%$ of $\mathrm{A}$ sera containing anti- $B$ isolysin [8] to more than $90 \%$ of $O$ and $B$ sera containing anti-A isolysin [4]. Reports of many other wide-ranging values have led to the general assumption that isolysins, in contrast to ABO isoagglutinins, do not follow the rule of Landsteiner.

It has been suggested that one important reason for such variable values lies in variable levels of sensitivity of the methods used in the several studies; the possibility exists that a sufficiently sensitive test would show isolysins in all the sera in which Landsteiner's rule would predict them. Thus by increasing the amount of serum per cell up to $200: 1$, and using ${ }^{51} \mathrm{Cr}$ release from labelled $\mathrm{A}$ cells as a measure of hemolysis, Polley et al. [6] concluded that all $O$ sera lyse A cells.

In this study the spectrum of $\mathrm{ABO}$ isolytic activity of human sera was determined by a simple direct test which permits the detection and relative quantification of frank hemolysis.

\section{Method and Materials}

The method for testing hemolysins consists of 4 steps:

(a) Preparation on a thoroughly clean glass slide of a $1.5 \mathrm{~mm}$ thick layer of $1 \%$ agar gel in physiological salt solution, plated at not over $40^{\circ} \mathrm{C}$, in which human

1 Supported by NIH grant HD 03470.

Received: December 2, 1970; accepted: January 27, 1971. 
red cells of the appropriate blood group are suspended; $5 \mathrm{~mm}$ wells are cut in the gel plate.

(b) The wells are filled with the sera to be tested; it diffuses from the wells into the agar sensitizing the red cells if it contains the specific lysin (sera are completely absorbed from the well in 12-14 h).

(c) The wells are refilled with rabbit serum complement (free from anti-human lysins) and the preparation is kept at $37^{\circ} \mathrm{C}$ until the complement is completely absorbed $(6-8 \mathrm{~h})$. Complement diffusing from the well produces lysis of the red cells surrounding the well when these have been sensitized.

(d) The border of the wells is inspected macroscopically or microscopically to determine the presence or absence of the characteristic halo of lysis and to measure its width (fig. 1).

Quantification. Given an excess of complement, the width of the halo of lysis should be a measure of the amount of hemolysin contained in the serum. Thus, lowering antibody titer by diluting the serum produces progressively narrower halos. When the width of the halo is plotted against the logarithm of the relative antibody concentration, the relationship is linear.

Sera. A total of 292 human sera obtained from a blood bank were tested for anti- $A$ and anti-B isolysins with this method, against $O, A$, and $B$ human red cells; 42 sera $(12 \mathrm{O}, 3 \mathrm{~A}, 16 \mathrm{~B}$, and $11 \mathrm{AB})$ were tested for the presence or absence of isohemolysins; in 250 sera $(104 \mathrm{O}, 89 \mathrm{~A}$, and $57 \mathrm{~B})$ isolytic activity was quantified. The donors (75\% male, 25\% female) ranged in age from 19 to 61 years with an average of 35.7 years ( 36.2 for males, 34.2 for females). The sera were separated from the clot in the pilot test tube accompanying each unit for transfusion within $48 \mathrm{~h}$ and were used immediately or stored frozen $\left(-20^{\circ} \mathrm{C}\right)$ no longer than 15 days before testing.

Red cells. $O, A_{1}$ and $B$ group human red cells were used in the agar layers after being stored in their own serum at $4^{\circ} \mathrm{C}$ no longer than 2 days.

Complement. Fresh complement was obtained for each of the 7 lots from normal adult New Zealand rabbits by cardiac puncture. Sera for complement were absorbed with $2 \mathrm{ml}$ of packed washed red cells from the same samples used for the preparation of the layers of agar gel in each experiment.

Protocol. The 250 sera were distributed at random in 7 lots of 36 each. Each lot was tested against $O, A_{1}$ and $B$ cells from the same 3 donors, but 3 different individuals were used for each of the 7 lots. In no cases were the cells taken from one of the sera being tested. Coding was used such that the assayist was not aware of the type or the source of the sera.

Fig. 1. (Upper) Negative and positive hemolytic reaction in agar gel. Low power magnification view of 2 adjacent wells in agar containing $A_{1}$ red cells. The left well was filled with group $A$ human serum and then refilled with absorbed rabbit serum; there is no hemolytic halo. The right well was filled with $O$ serum and then with the rabbit serum; the clear halo indicates a positive hemolytic reaction. For photography, agar and wells were covered with saline and a green filter was used. (Lower) Microscopic view of the upper border of the 2 wells shown above. A negative reaction is identified by the absence of hemolysis; a positive reaction is shown by the clear halo of hemolysis in which the agar is transparent and free from cells. Length of scale $=1 \mathrm{~mm}$ in the preparation. 


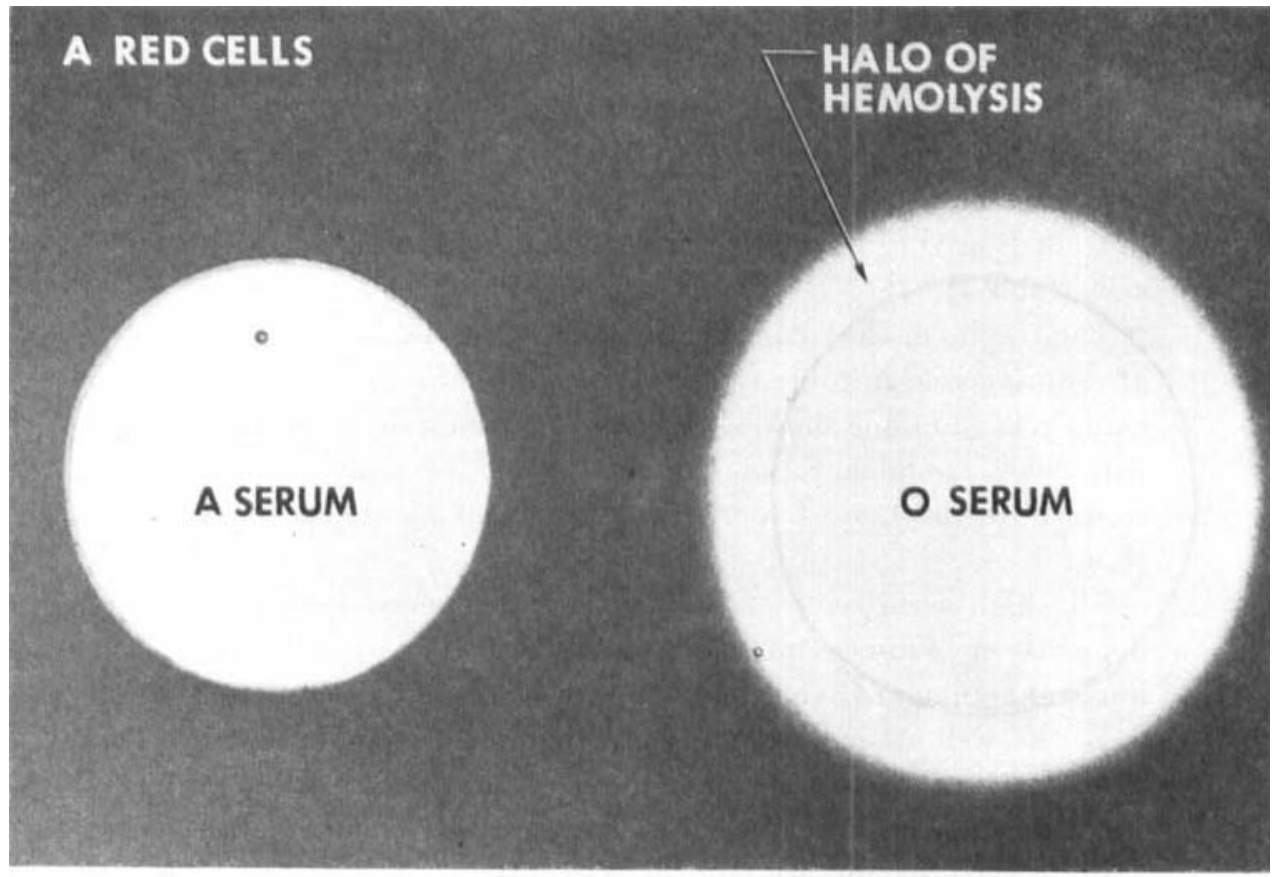

\section{A SERUM}

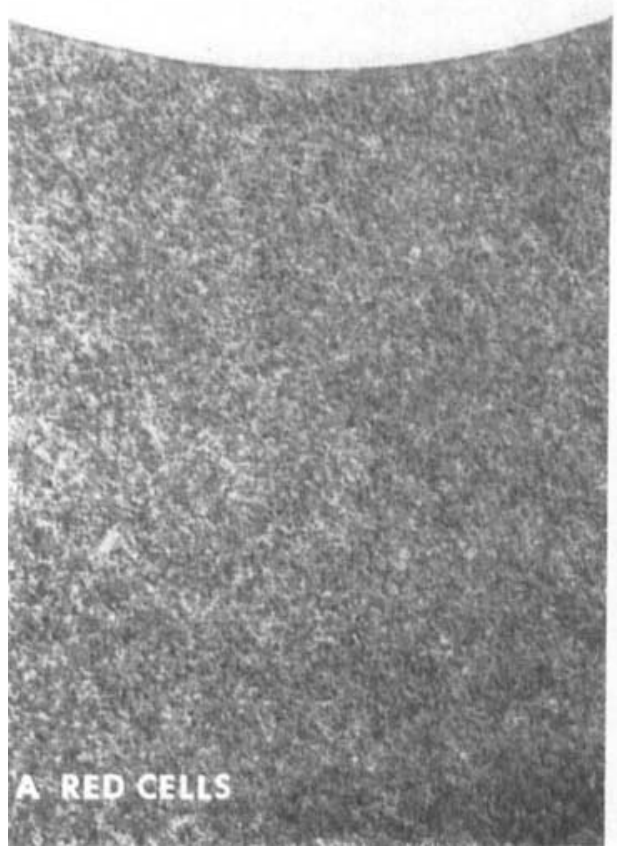

O SERUM

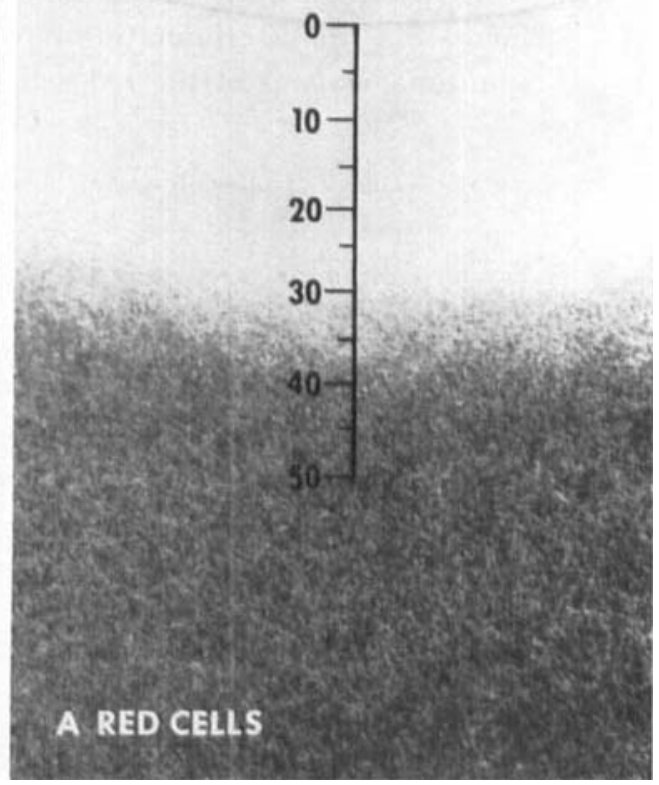




\section{Results}

Of the 292 human sera tested: (a) all of the 1160 sera lysed $A_{1}$ and $B$ cells but did not lyse $O$ cells; (b) all of the 92 A sera lysed $B$ cells, but not $A_{1}$ or $O$ cells; (c) all of the $73 \mathrm{~B}$ sera lysed $A$ cells, but not $B$ or $O$ cells; and (d) none of the $11 \mathrm{AB}$ sera lysed $A, B$, or $O$ cells (table I).

The results of the quantification of the isolytic activity in 250 sera are summarized in table I. Since all of the sera showed the expected hemolysis and none showed an unexpected isolysin, one can conclude with $99 \%$ confidence that at least $99.7 \%$ of the total population conform to the Landsteiner rule for isolysins as well as for isoagglutinins.

The high sensitivity of the well test described here presumably depends on factors related to: (a) lability of red cells (cells appear less stable in agar than saline); (b) amount of lysin per cell (diffusion from the well assures exposure of a minimum number of cells to as much lysin as they can absorb); and (c) kind, concentration, and preservation of complement (rabbit serum ideal) [2,3]. MoLlison [5] pointed out the importance of those factors in obtaining positive hemolytic reactions with all anti-A sera, and GrundBacher [3] used two of these same factors to increase the sensitivity of his method.

The localized lytic effect around the well is an important factor in increasing the discriminating power of the test. The background of spontaneous lysis of the red cells during the experiment is uniform

Table $I$. Isohemolytic anti- $A$ and anti-B activity in human sera

\begin{tabular}{|c|c|c|c|c|c|}
\hline \multirow{2}{*}{$\begin{array}{l}\text { Serum } \\
\text { blood } \\
\text { group }\end{array}$} & \multirow{2}{*}{$\begin{array}{l}\begin{array}{l}\text { Number } \\
\text { of } \\
\text { sera }\end{array} \\
116\end{array}$} & \multicolumn{2}{|c|}{ 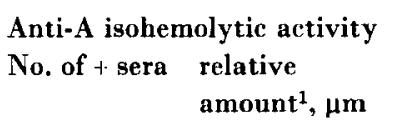 } & \multicolumn{2}{|c|}{$\begin{array}{l}\text { Anti-B isohemolytic activity } \\
\begin{array}{l}\text { No. of + sera } \\
\text { relative } \\
\text { amount }^{1}, \mu \mathrm{m}\end{array}\end{array}$} \\
\hline & & 116 & $274 \pm 14(104)^{2}$ & 116 & $214 \pm 17(104)$ \\
\hline A & 92 & 0 & $0 \quad(89)$ & 92 & $169+8(89)$ \\
\hline B & 73 & 73 & $162 \pm 8(57)$ & 0 & (57) \\
\hline $\mathbf{A B}$ & 11 & 0 & $-\quad(0)$ & 0 & (0) \\
\hline Total & 292 & 189 & $(250)$ & 208 & (250) \\
\hline
\end{tabular}

1 Given by the width of the halo of lysis.

2 Number in parenthesis indicates the number of sera in the quantitative study. 
throughout the layer of agar; thus when a high proportion of red cells in the agar have spontaneously lysed, the presence or absence of isolytic activity in the test material can be easily established.

Quantitative results show a wide variation in the content of each isolysin within each blood group, but the relative levels of the average concentrations are comparable to those from quantitative studies on isoagglutinins $[1,7]$ and to other quantitative estimates of relative hemolysin content [4] (table I).

\section{Summary}

A simple, sensitive agar-well test for the detection and quantification of hemolysis is described and applied to a survey of anti-A and Anti-B isolysins in human sera. The isolysins were present in all the sera in which they should be expected according to Iandsteiner's rule, thus indicating, with a high degree of confidence, that both anti-A and anti-B isolysins are as universal in healthy human adults as the corresponding isoagglutinins.

\section{References}

I. Aubert, E. F.; Boorman, K. E.; Dodd, B. E., and LouttT, J. F.: The universal donor with high titer iso-agglutinins; the effect of anti-A iso-agglutinins on recipiens of group $A$. Brit. med. J. i: 659 (1942).

2. Dennis, H. G. and Konugres, A. A.: Comparative studies of the effectiveness of complement obtained from different species in the $a$-haemolysin test on human sera. J. med. Lab. Technol. 16: 284 (1959).

3. Grundbacher, F. J.: Immunohemolysis as a method for quantitation of the A antigen of human erythrocytes. J. Immunol. 93: 205 (1964).

4. Grundbacher, F. J.: Quantity of hemolytic anti-A and anti-B in individuals of a human population: correlation with isoagglutinins and effects of the individual's age and sex. Z. Immun Forsch. 134: 317 (1967).

5. Molisson, P. I.: Blood transfusion in clinical medicine, 4th ed., p. 253 (Blackwell, Oxford 1967).

6. Polley, M. J.: Adinolfi, H., and Mollison, P. L.: Serological characteristics of anti-A related to type of antibody protein (7S $\gamma$ or $19 \mathrm{~S} \gamma)$. VoxSang.'8: 385 (1963).

7. Thomsen, O. und KetTer, K.: Die Stärke der menschlichen Isoagglutinine und entsprechenden Blutkörperchenrezeptoren in verschiedenen Lebensaltern (the concentration of human isoagglutinins and corresponding erythrocyte receptors in different ages). Z. ImmunForsch. 63: 67 (1929).

8. Tovey, A. D.: The incidence, distribution and life history of the anti- $A$ and anti- $B$ hemolysins in the general population. Vox Sang. 3: 363 (1958).

Authors' address: Dr. L. Daufi, Research Associate, and Dr. P. Ronnfit, Associate Professor, Department of Physiology, University of Michigan Medical School, Ann Arbor, Mich. (USA) 